Article

\title{
New Frontiers in Travel Motivation and Social Media: The Case of Longyearbyen, the High Arctic
}

\author{
Carolina Aldao ${ }^{1, *(1)}$ and Tanja A. Mihalic ${ }^{2}$ (D) \\ 1 Faculty of Tourism, University of Girona, 17004 Girona, Spain \\ 2 Faculty of Economics, University of Ljubljana, 1000 Ljubljana, Slovenia; tanja.mihalic@ef.uni-lj.si \\ * Correspondence: carolina.aldao@udg.edu
}

Received: 29 June 2020; Accepted: 20 July 2020; Published: 22 July 2020

\begin{abstract}
Tourism explores new frontiers by traveling around unknown geographical and technological territories that bring new tourism opportunities and hazards to satisfy visitors' needs and sustainability and responsibility in destinations. This study introduces a composite model for measuring travel motivation and the impact of social media on travel behavior and applies it to the town of Longyearbyen in the High Arctic. Both aspects were surveyed through qualitative semi-structured visitor interviews. While the motivation to visit Longyearbyen depended on travelers' needs, their travel experiences, and push and pull motivational factors, respondents gave examples of how social media positively or negatively affected different elements of their motivation and visitation. The study indicates the opportunities and hazards analyzed from social media as well as future research directions needed in the pursuit of a more responsible tourism approach while exploring new technological and geographical frontiers.
\end{abstract}

Keywords: travel motivation; travel behavior; social media; the High Arctic; responsible tourism

\section{Introduction}

Despite climate change, temperature increases, and travelers' awareness of the negative impacts of pollution, mainstream tourism remains at beach and urban tourism destinations. However, the growth of tourism, the development of transport, technology, and economies, increased travel motivations, and new lifestyles and values have brought world travel to a new frontier. Tourism explores new horizons and spreads travel around "unknown opportunities and perils" [1] such as unknown geographical and technological territories as the Arctic, bringing new opportunities and hazards to satisfy visitors' needs and travel motivations.

While many studies have investigated travel motivations, few connect the cases concerning the Arctic regions [2]. Recent studies have addressed travelers' motivations in specific types of tourism such as dark tourism and volunteer tourism [3-5]. However, little research has regarded travel motivations and the influence of social media in the High Arctic. On the one hand, previous studies on the motivations behind visiting a destination have separately focused on Maslow's [6] hierarchy of human needs, Pearce's [7] travel career ladder theory, and Crompton's [8] push and pull motivation factors. Although these theories are connected, when combined, they offer a comprehensive list of motivational elements that become relevant for the study of travel behavior. On the other hand, upon recognizing its massive influence on travel decisions, social media has become an undeniable factor in the management of travel behavior and the influence behind visiting a destination.

This paper aims to analyze the travel motivation behind visiting Longyearbyen, the High Arctic, by proposing a relevant model from which to analyze travel motivation elements alongside the impact of social media and the opportunities and hazards. Further, this research seeks to shed light on the driving forces that lead tourists to visit the northernmost town in the world. Based on social 
media influence studies, we investigate the opportunities and hazards of these platforms to discover whether social media promotes or inhibits motivation for responsible tourism when visiting this destination. This study could help destination managers to get the most out of a destination by paying attention to both tourists' needs and the influence of social media, while simultaneously preserving the environment by promoting responsible tourism at the destination. The following research questions represent the basis of this study: (1) What motivates people to travel to Longyearbyen, the High Arctic? (2) How does social media influence travel motivation to visit Longyearbyen?

This paper is presented in seven sections. The existing knowledge on travel motivation and the impact of social media on travel behavior is presented, and the gap in rationale is identified. A short presentation on Longyearbyen follows to provide geographical context and to allow the reader to understand the realistic conditions in the High Arctic. Subsequently, the qualitative research approach and design are presented, which forms the basis for the semi-structured interview research plan. The study's findings and discussion are presented, and the conclusion summarizes how the study's aim has been achieved. The study's limitations, topics for future research, and responsible tourism implications are also discussed.

\section{Longyearbyen, the High Arctic}

Longyearbyen is the administrative center of Svalbard, a Norwegian archipelago located between mainland Norway and the North Pole (Figure 1). It has 2150 inhabitants and it is located at 78 degrees north, which makes this destination the northernmost populated town in the world [9]. Longyearbyen represents the hub for exploring the Svalbard archipelago as both the most populated town and the only one that provides infrastructure and services. The archipelago experiences extreme weather during the winter, and temperatures can reach $-30{ }^{\circ} \mathrm{C}$. However, due to the Gulf Stream, temperatures are milder when compared to other Arctic regions in mainland Norway that experience more extreme temperature variations [10].

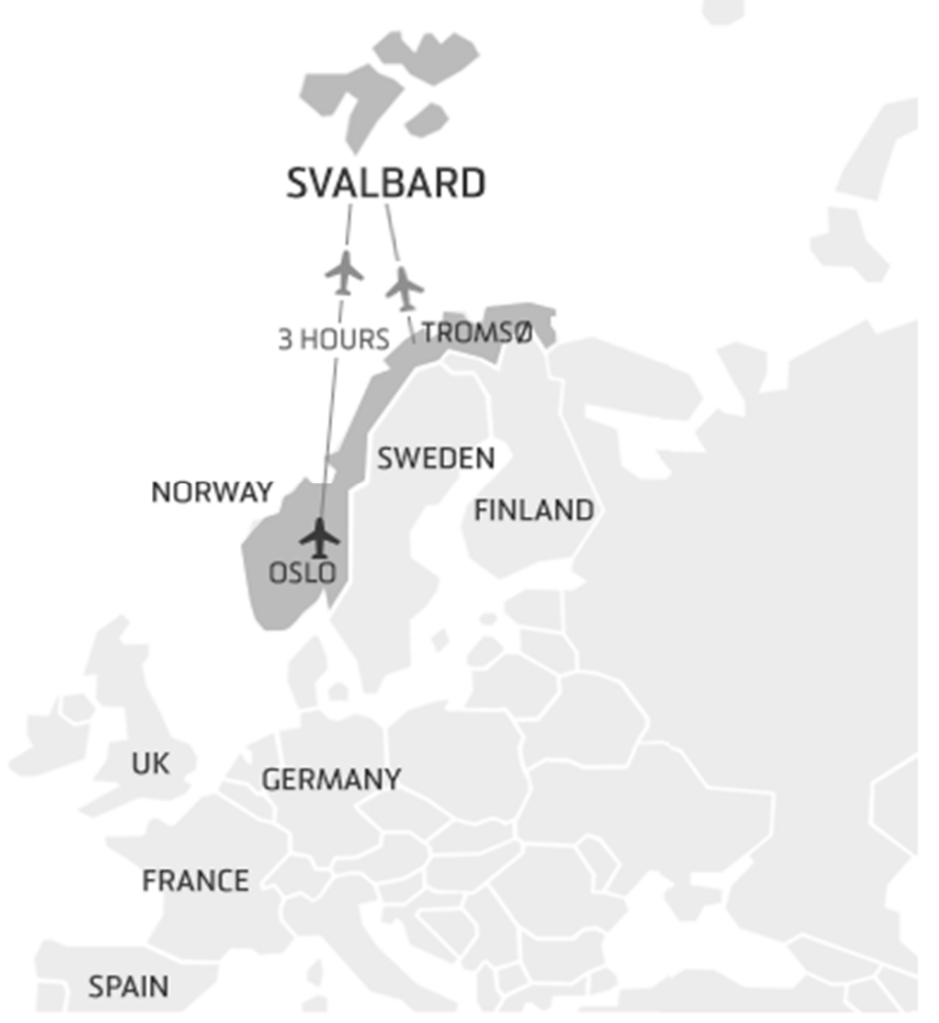

Figure 1. Location of the Svalbard archipelago. Source: Visit Svalbard [11]. 
Longyearbyen has recently become a destination not only for explorers but also for leisure tourists. According to Visit Svalbard [12], the archipelago received 72,544 tourists in 2018-76\% more when compared to the 41,037 tourists in 2008. Since 2011, Longyearbyen has experienced an average yearly increase of visitors (between $3 \%$ and $20 \%$ ), and tourism is still growing according to statistics. For this reason, tourism is shown as being in high demand, and the basis of the motivation to visit the High Arctic is primarily the chance to experience a close encounter with the North Pole [10]. Within the High Arctic, Longyearbyen is a destination that is still unknown by many, as the Far North is often considered an uninhabited and unreachable place [13].

Today, Svalbard's economy is supported by three pillars: the coal mining industry, tourism, and research, in that order. The town is named after the American industrialist John Munro Longyear, a central figure in Svalbard's coal mining industry. It was first named Longyear City but was changed to Longyearbyen, since "byen" means "city" in Norwegian [8]. Research became relevant once the University Centre was established in Svalbard in 1993-a Norwegian institution specializing in biology, geophysics, and geology [14,15]. Tourism became important in 1975 when the Longyearbyen airport opened. This event represented a milestone by allowing the destination to be accessible to everyone [10]. However, this is not the only gateway to Svalbard, since many cruise ships arrive in Longyearbyen, especially during the summer. However, most tourists are Norwegians from the mainland, who represent $65 \%$ of the total number of tourists [9]. To demonstrate the importance of the cruising industry, according to the Association of Arctic Expedition Cruise Operators [16], Svalbard received 62,342 cruise passengers in 2018: $14 \%$ less than the total amount of tourists received by the archipelago in the same year. This difference lies in the fact that those arriving by ship are not counted as tourists, since they do not stay overnight. At present, there are two types of cruises: conventional and expedition. The former is represented by cruise operators that offer international itineraries, where Longyearbyen represents one of many stops. Expedition cruises are represented by smaller vessels that make several stops to remote areas of Svalbard and aim to have close encounters with the Arctic marine fauna [17].

Since the 1990s, the Norwegian government has paid special attention toward fostering tourism, which has become the main economic support for many families living in Longyearbyen [18]. Moreover, the town has recently experienced rapid urban development. As a point of reference, up until 2010, Longyearbyen had only two hotels. Currently, there are 14 places to stay overnight: four are hotels and the rest are apart-hotels, bed and breakfasts, and one hostel. There are also several restaurants and souvenir shops, one supermarket, the North Pole Expedition Museum, and the Coal Mine 3 museum. Further, there is a hospital that has six beds, a primary and secondary school, a swimming pool and sports center, a cinema, and a library [19].

It is important to emphasize that Svalbard is mainly promoted as a hub for nature-based activities, as $98 \%$ of the entire Svalbard archipelago is represented by wilderness. As such, Longyearbyen attracts tourists who are willing to experience an adrenaline rush from snowmobiling, dog sledding excursions, hiking activities, crossing glaciers and fjords, visiting ice-caves, and watching the Aurora. During the winter, participants of these activities are exposed to low temperatures [20,21]. However, snowmobiling is a popular activity as no experience is needed (just a valid driving license). The most popular destinations are Adventdalen, Tempelfjorden, the east coast, and the Russian towns of Barentsburg and Pyramiden [9].

In addition, Longyearbyen is a popular place to see the Aurora. The Polar Nights season runs from November 11 to January 30 and is also known as the dark season, meaning that the sun does not appear at all. This phenomenon allows visitors the chance to see the Aurora $24 \mathrm{~h}$ a day; however, all excursions must be conducted by authorized guides. According to Statistics Norway [9], Svalbard has 3000 polar bears around the archipelago. A polar bear sign located two kilometers away from the center of the town indicates that, for safety reasons, it is mandatory by law to carry a rifle at all times. Further, this region features polar foxes and 19 species of maritime fauna such as walruses, seals, and whales. Tourists depend entirely on the use of private transportation, which means that all 
excursions are either run by buses, cars, snowmobiles, and snow tracks during the winter, or cruises or vessels during the spring and summer.

Nature-based activities are sensitive when exposed to tourism activity, and may spoil the archipelago's wilderness and biodiversity [17,22-25]. As Svalbard still has untouched and unspoiled territories, its remoteness represents an attractive feature to visitors $[17,26]$. However, the implementation of the new term, "last-chance tourism," is a consequence of the rapid deterioration of the environment and has put Svalbard in the public eye $[27,28]$. Therefore, keeping tourism sustainable and responsible is of high importance for further tourism development.

\section{State of the Art}

\subsection{Motivation as the Driving Force behind Travel}

The study of travel motivation has always had a background in sociological theories [29] and has been deeply studied within the literature on tourist behavior [30]. Motivation can be defined as a response that satisfies a deprivation. Following this concept, travel motivation is described as "the driving force behind tourist behavior" [31], and assesses what is behind the needs of human beings in order to understand tourists' behavior, and focuses on the causes that make a tourist decide to travel. Hence, it is imperative to mention Maslow's [6] hierarchy of needs: the theory that became the basis of studying the impacts of human motivation and behavior.

Based on Maslow's theory, Pearce [7] introduced the travel-specific career ladder theory, which could be described as a "motivational career in travel" [32]. This theory argues that motivation changes according to the past travel experience of the tourist (Figure 2), and that building a personal career in traveling is like climbing a ladder toward reaching one's self-actualization needs [33]. As such, more experience in traveling leads to an increased likelihood of being willing to reach the top of Maslow's hierarchy of needs, that is, one's self-actualization needs, which means having the utmost potential regarding skills, creativity, knowledge, maturity, and autonomy [34-37]. Therefore, it is likely that a tourist in their early traveling career might seek to satisfy the first levels of Maslow's theory, and those already in the maturation stages of traveling might seek to venture to the top of Maslow's pyramid of needs [6]. Moreover, experienced travelers tend to feel more confident and independent and are willing to challenge themselves to new adventures when compared to inexperienced travelers, and consequently search for new travel frontiers [34]. Further, those with experience are more likely to actively participate at a host site by expressing interest in the people and their local traditions, culture, and surroundings. Thus, these characteristics show that experienced travelers have more determination in themselves and have spontaneity toward others [38].

However, the concept of the travel career ladder is not fixed or rigid. It may be that a person might feel the necessity to change their needs when planning a trip, or that they have some financial eventualities or any other reason that could mold their motivation to travel. To avoid rigidity in reaching the top of a travel career in the sense of progressing via a straight ladder, one should incorporate dynamism that includes being forward and backward in one's travel behavior. Therefore, it appears that the concept of "patterns" will allow for a more dynamic approach toward having a motivational career in travel for those that follow a passion or specific hobby [38-40]. In this regard, a person might be exploring new frontiers of travel in terms of geography; local traditions in terms of novelty or education; or returning to known frontiers such as beach or urban destinations.

Accordingly, travel motivations can be studied from many perspectives to allow an understanding of why people choose one destination among others [8]. Travel motivation is special, as people travel to seek pleasure or something new or different to compensate for the emotional stress of their daily routine, and escape from the imbalances caused by everyday problems [41]. This perspective analyzes the concept of the push and pull factors that establish the differences between what "drives the tourist to leave their current situation" (push factors) and what "encourages or attracts the tourist to the vacation destination" (pull factors) $[38,42,43]$. Therefore, since traveling is a two-way approach, 
push motivations need pull motivations to satisfy tourists' needs [31]. Both forces motivate a tourist to reach a destination that is perceived as being different and more attractive when compared to their daily routine [44]. Moreover, according to Dann [45], the internal need to be fulfilled precedes the visit to the desired place. According to this concept, Crompton [8] defined seven push motivations that represent the basis of satisfying emotional needs, and two pull motivations that constitute the cultural features of a destination (Figure 2). Among the push factors, the "escape from the mundane" involves the need to change one's routine environment by being somewhere else; "exploration and self-discovery" relates to exposing oneself to unusual contexts; "relaxation" implies calming both the psyche and the body; "prestige" is represented by appreciating the value of a destination's features; "regression" deals with the different inner sensations in uncommon situations; "enhancement of kinship relations" represents the chance of building stronger bonds with family and peers; and the "facilitation of social interactions" refers to the chance to meet new people. On the other hand, the pull factors allow to identify when, where, and how people travel $[46,47]$. The pull factors are defined by "novelty" and "education," meaning that a destination should ensure some aspects of learning during the travel experience alongside the chance to discover new places that will lead to an appreciation of their uniqueness $[8,48]$.

Recent studies in travel motivation have taken Maslow's [6], Pearce's [7], and Crompton's [8] studies and applied them to empirical cases. In this way, different perspectives and alternative frameworks have been elucidated to investigate, for example, the role of emotional components of travel motivation in travel behavior [49]; differences among tourists' motivations to travel to different destinations [50]; first-time and repeated travel motivations [51]; motivation and satisfaction in relation to destination loyalty [52]; a model that integrates the concept of expectation, motivation, and attitude [53]; and the study of push and pull motivations in cruise tourism [54] in order to understand tourists' behavior and visit intentions [55].

\subsection{Social Media's Impact on Travel Motivation}

The rapid evolution of social media as a communication tool has brought destinations closer to potential travelers as social media influences the decisions that tourists are taking when deciding on a destination $[56,57]$. These platforms are the primary sources for sharing travel experiences, especially among millennials $[58,59]$. Moreover, social media offers an interactive way for destination management and marketing organizations to contact travelers and foster their engagement [57]. In this regard, users co-create a virtual context and travelers become the "co-designers, co-producers, co-marketers, and co-consumers of tourism experiences" [60]. Social media enables experiences to be widely and publicly shared, alongside the creation of a virtual community where travelers help each other. In this way, travelers experience satisfaction by receiving other tourists' opinion and information about a destination, its services, and attractions [61]. Instagram and Facebook represent two examples of popular social networking sites $[62,63]$. Although their contents do not aim to be strictly travel-related, both serve as inspiring sources for in-depth discoveries of destinations and allow one to get closer to local suppliers and destination managers (Figure 2). Moreover, they shorten the gap between the destination and the traveler by allowing everyone to participate and openly share their experiences [64]. Simultaneously, social media reduces the distance toward new frontiers in terms of geography, novelty, and education by bringing a destination to one's living room and making them part of everyday life [65].

Social media hashtags allow one to follow any topic of interest and provides the chance to receive constant updates from other users, thus enabling contact with first-hand information sources [66]. Travel motivation is raised, and an expectation is created before experiencing the place "in-situ." Consequently, an emotional connection is initiated before the physical act of traveling to the destination. All participants are rewarded, as the user that is already at the destination is satisfied by having the chance to share their experience, and the traveler that is willing to visit a destination is compensated 
by receiving feedback [67]. Therefore, Facebook and Instagram have reduced uncertainties in travel planning and have helped gain familiarity with a new destination (Figure 2).

Travel interest has become a product of global mass collaboration. Owing to the use of social media, the image of a destination could be perceived as being negative or positive as it is the users' content that creates an idea of the destination beforehand [68]. Online word-of-mouth through social media has the power to impact tourists' intentions to travel [56]. There are two primary reasons that motivate people to share their travel experiences on social media. The first concerns an intrinsic aim, meaning a self-interest in traveling. This motive serves as a source of inspiration for others. The second motive, also known as an extrinsic factor, lies in the fact that interest in traveling is awakened by the need to gain recognition from others and enforce one's self-esteem by displaying travel achievements [66]. Vannucci, Flannery, and Ohannessian [69] observed that greater exposure to social media displays greater anxiety in users. Further, social media represents platforms that spawn jealousy by fostering social anxiety among the travel community from the phenomenon referred to as "FOMO," the fear of missing out (Figure 2), which is defined as "a pervasive apprehension that others might be having rewarding experiences from which one is absent" [70]. Therefore, there is a need to constantly check for updates on social media to scrutinize what one's peers are doing. The users that need extrinsic motivations to travel put pressure on themselves to be recognized as a reference point of a travel trend [71].

In addition, social media produces a counter-productive effect on tourism by massively overexposing some destinations (Figure 2), thus making certain places in danger of ceasing to exist due to climate change. Many tourists publicly share pictures and content to raise awareness of the vulnerability of a place [72], yet simultaneously are not conscious of the fact that this action awakens the anxiety of others that are thinking about visiting that destination before it disappears, and therefore strongly impacts the sustainability of the destination. Consequently, these affected destinations are known as "last-chance tourism destinations" and become part of a "bucket list" of places to visit. As such, travelers feel rewarded from having the chance to experience and get the most out of a place that will deteriorate in the near future, and simultaneously gain self-confidence and recognition from their peers [73].

Finally, social media helps debunk popular misconceptions (Figure 2) as the mass audience of users can come closer to the current experience of a traveler at a destination, and pictures and videos uploaded on Facebook and Instagram help to shorten the gap between the real and the imaginary. Social media has become an opportunity for travelers to raise their levels of self-confidence at the same time as facing their fears to travel to a specific destination. As such, preconceptions can be demystified since social media enables the belief that any destination is accessible [66,67]. 


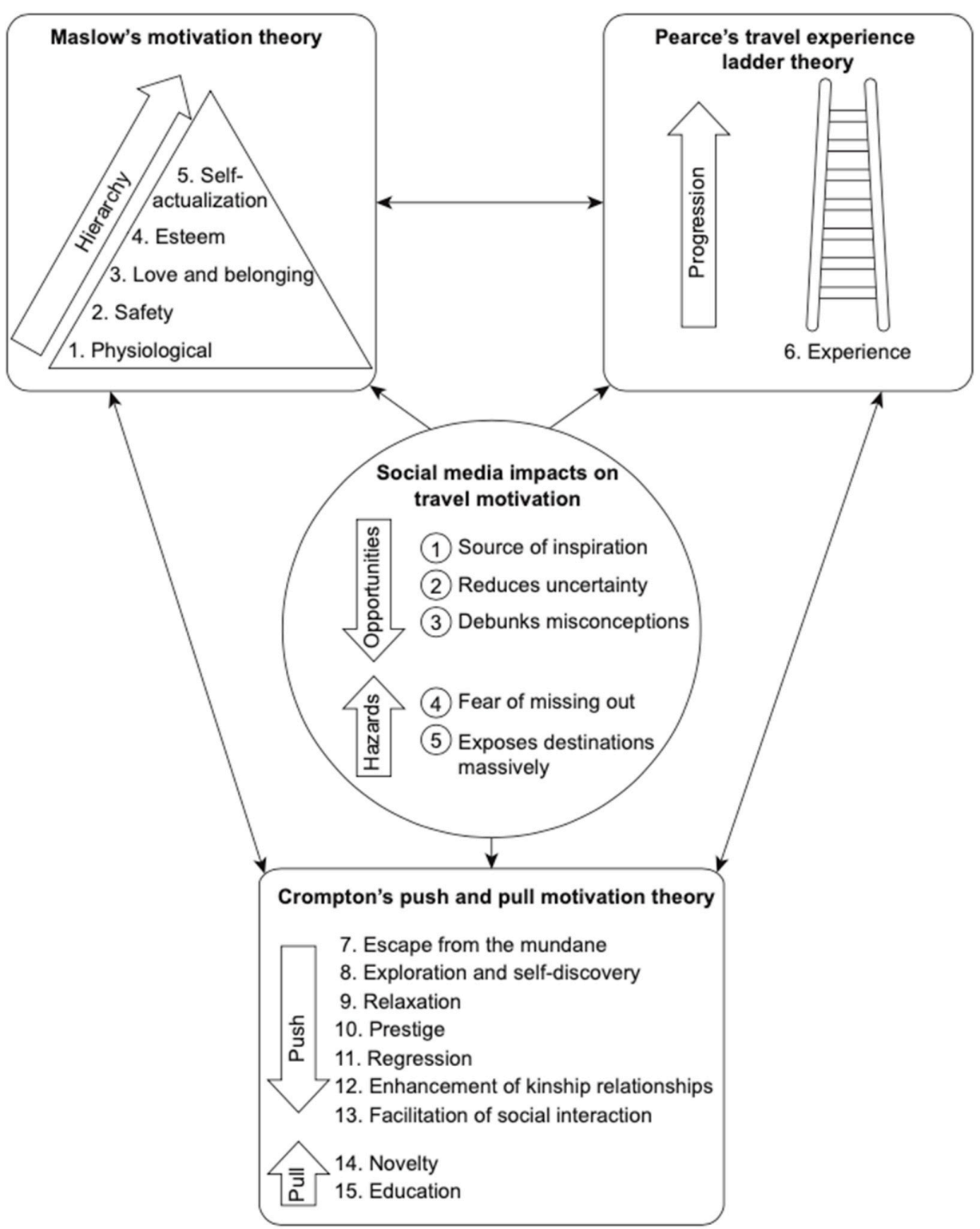

Figure 2. Travel motivation and social media. Source: Adapted from Maslow [6]; Pearce [7]; Crompton [8]; Mariani, Ek Styven, and Ayeh [66]; Fatanti and Suyadnya [67]; Llodra-Riera, Martínez-Ruiz, Jiménez-Zarco, and Izquierdo-Yusta [68]; Przybylski, Murayama, DeHaan, and Gladwell [70]; and Lemelin, Dawson, Stewart, Maher, and Lueck [73].

\section{Research Design, Methodology and Data}

\subsection{The Impact of Motivation and Social Media on Decisions to Travel to the High Arctic}

As Viken [74] stated, "there is no doubt that tourism in the Arctic is different from tourism in other areas." However, since the 1990s, tourism in Longyearbyen has experienced rapid growth and the number of tourists has almost doubled in the last 10 years. Therefore, this study's first research question aims to understand the choices behind deciding to travel to Longyearbyen by analyzing tourists' motivational needs, their past experiences and expectations, and the push and pull factors of motivation. The second research question emphasizes the role of social media on travel motivations to Longyearbyen. Figure 2 presents the research design and connects travel motivation elements with social media opportunities and hazards by joining 15 different elements for travel motivation and 
five aspects of social media addressed in the previous research. The proposed model assumes that social media influences all elements of motivation that have been discussed to date in tourism literature.

This study's investigation uses qualitative analysis as the core focus is to analyze travelers' motivations in depth and to understand their reasoning rather than focus on numbers and statistics. This method was chosen to become personally involved with tourists at the destination and establish a deeper connection when approaching them. Therefore, semi-structured interviews with open-ended questions were conducted to enrich the data by collecting more information from participants. Data were gathered in Longyearbyen, Svalbard, between February and March 2019, under normal circumstances; that is, when travelers were joining activities and excursions $[75,76]$. However, this research process implies a subjective view since it is based on personal observations, analysis, and interactions with participants. While all perspectives were equally considered, it is imperative to state that the following sample does not represent the whole population. The research results are exclusively related to the sample taken and transferred into words and are not in terms of numbers [75].

The size and small population of Longyearbyen made the research quite simple, as all tourists were easily visible in the center of the town. As the town is in the shape of a cross, the two main roads represented the starting point from which to encounter travelers. Most were found on the main pedestrian roads and in souvenir shops, the supermarket, and the museums. As the outside temperatures were between -20 and $-30^{\circ} \mathrm{C}$ during the interview period, most of the people wandering the streets were tourists.

The study was developed through two important phases: secondary data and in-depth research. The first phase concerned conducting research about the facilities, accommodation, weather, activities, and attractions in Longyearbyen through secondary data. In addition, the hashtags "\#Longyearbyen" and "\#Svalbard" were followed on Instagram to become familiarized with the destination itself and to receive updates from other tourists or events that were currently being held in the town. The second phase, presented in this paper, was the beginning of the in-depth part of the research and concerned a thorough understanding of tourists' travel motivations to represent the study's focus. Interviews were conducted in relaxing atmospheres such as at the end of excursions, when tourists were visiting museums, and while shopping. Interview questions were accurately prepared beforehand to gain as much information as possible in the shortest amount of time. A list of questions related to the elements of Figure 2 was essential to analyze both the tourists' motivations in visiting Longyearbyen and social media's impact on their travel behavior.

The first part of the interview questions involved asking the nationality, with whom they were traveling, the age, profession, length of stay, activities conducted, and if the trip included any other destinations. These questions were aimed at understanding the target group of the visitors to Longyearbyen. For the motivation aspect, respondents were asked how they first discovered Longyearbyen, how they imagined it to be before arriving, why they preferred to visit during February or March, and why such a cold place was chosen over a warm one. Further, respondents were asked what most attracted them to visit this destination, and for the main goal of the trip in relation to their inner desires or necessities that they sought to fulfil. Finally, the last questions concerned social media and were directed at those who were frequent users. They were asked if social media had had any influence on the decision to visit Longyearbyen, if their perception of this destination changed after having seen pictures or videos posted online, and if social media had helped them ease their worries and fears before arriving. In total, 50 interviews were conducted: 28 in Longyearbyen and 22 via the private message function on Instagram to followers that were publicly posting pictures or videos of their trip with the hashtags "\#Longyearbyen" and "\#Svalbard."

\subsection{Data}

According to Visit Svalbard [12], most tourists come from mainland Norway, followed by Sweden, Germany, the United Kingdom, France, the Netherlands, Italy, Denmark, Switzerland, Poland, Spain, Belgium, and Finland. Non-European travelers come from the United States, Russia, 
China, and Australia. When comparing these data to the interviews conducted, most of these nationalities coincided. However, some other nationalities that did not appear in the statistics were present such as travelers from Argentina, Brazil, India, Greece, Ireland, Turkey, Ukraine, and Thailand. However, these were isolated cases.

According to the respondents, Longyearbyen is an expensive destination and is not considered as a last-minute opportunity. The reasons for visiting were mostly coherent and were supported by special interests. It is important to remember that Norway has a strong currency and Svalbard is not an exception; thus, traveling to the northernmost town in the world involves investing both effort and money. As such, respondents tended to stay for an average of four nights according to the interviews. In addition, there are few flight offers; Scandinavian Airlines and Norwegian Air are the only two airlines that fly to Longyearbyen. In terms of accommodation, most hotels are more expensive when compared to other Nordic destinations [19]. Moreover, excursions are very costly, as all involve transportation, local guides, and special equipment. This illustrates why Svalbard is considered as a niche destination. Most of the respondents were professionals or skilled workers such as engineers, physicists, accountants, economists, auditors, or consultants, or worked in the sales, design, tourism, and educational industries, or the scientific and health sectors. Few students were present, except for some master's students.

Of the total 50 interviews conducted, $34 \%$ of the participants were solo travelers, $36 \%$ were couples, $14 \%$ were families with three or four members, and $16 \%$ were traveling with their friends. The majority were aged between their mid-20s to mid-40s; the entire range was from 5 to 60 years old. In addition, it is important to emphasize that although the study focused on February and March 2019, according to Visit Svalbard [12], these two months represent $17.5 \%$ of the total number of tourists that visited Longyearbyen in 2018, with February receiving 8.5\% of the arrivals and March receiving 9\%. Therefore, according to the analysis of the respondents' profiles, Table 1 details the 50 participants' gender, with whom they traveled, and their country of origin.

Table 1. Interview participants' demographics.

\begin{tabular}{|c|c|c|c|c|c|c|c|}
\hline No. & Gender & Traveling as & Country of Origin & No. & Gender & Traveling as & Country of Origin \\
\hline$\# 1$ & Female & Couple & Switzerland & $\# 26$ & Female & Family & The United States \\
\hline \#2 & Female & Solo & The United States & \#27 & Male & Couple & Alaska \\
\hline \#3 & Female & Friends & Italy & \#28 & Female & Solo & Sardinia \\
\hline$\# 4$ & Female & Friends & The United States & \#29 & Female & Couple & Germany \\
\hline \#5 & Male & Couple & The Netherlands & \#30 & Female & Solo & Ireland \\
\hline \#6 & Male & Couple & Russia & \#31 & Male & Couple & Argentina \\
\hline \#7 & Female & Couple & The United States & \#32 & Male & Solo & Turkey \\
\hline$\# 8$ & Male & Couple & Belarus and Switzerland & \#33 & Male & Solo & Turkey \\
\hline$\# 9$ & Female & Family & Norway & \#34 & Male & Solo & Norway \\
\hline$\# 10$ & Male & Family & Norway & \#35 & Male & Solo & Norway \\
\hline \#11 & Female & Friends & The United States & \#36 & Male & Solo & The United Kingdom \\
\hline$\# 12$ & Male & Friends & The United Kingdom & \#37 & Female & Solo & Norway \\
\hline$\# 13$ & Male & Couple & Brazil & \#38 & Male & Couple & Ireland \\
\hline \#14 & Male & Solo & India & \#39 & Male & Solo & The Netherlands \\
\hline \#15 & Female & Couple & The United Kingdom & $\# 40$ & Male & Friends & Denmark \\
\hline$\# 16$ & Male & Couple & Greece & \#41 & Female & Couple & Italy \\
\hline$\# 17$ & Male & Friends & Italy & $\# 42$ & Male & Solo & The United States \\
\hline$\# 18$ & Female & Friends & Mexico & $\# 43$ & Male & Solo & Sweden \\
\hline \#19 & Male & Family & France & $\# 44$ & Male & Solo & Ukraine \\
\hline \#20 & Female & Couple & France & $\# 45$ & Female & Solo & Norway \\
\hline \#21 & Female & Solo & France & \#46 & Male & Solo & Italy \\
\hline \#22 & Male & Couple & Norway & \#47 & Female & Couple & Thailand \\
\hline$\# 23$ & Male & Family & Spain & $\# 48$ & Female & Couple & Norway \\
\hline$\# 24$ & Male & Family & Spain & $\# 49$ & Female & Friends & China \\
\hline$\# 25$ & Male & Couple & Italy \& Spain & $\# 50$ & Male & Solo & Norway \\
\hline
\end{tabular}




\section{Travel Motivation and Social Media Analysis}

Travel motivation and social media's impact on visiting Longyearbyen have been previously discussed and follow this study's research design (Figure 2). The following results and analysis cover all 15 elements of the travel motivation-related theories by Maslow [6], Pearce [7], and Crompton [8] and are combined with the five elements of the influence of social media (Figure 2) and the interview respondents.

In the first element of the research design, the participants referred to their "physiological needs" (Figure 2, number 1). More specifically, in the surveyed context of the High Arctic, staying warm or having proper clothing is relevant, and this fear was revealed by $26 \%$ of the participants. For example, American respondent \#4 expressed that: "At home, it snows and gets quite cold, but not as much as here. I have heard that frostbite and polar bears represent a threat." Nevertheless, the cold represented the attractiveness of the Arctic, since many respondents chose the winter to visit so they could experience a "real winter." Many respondents emphasized that they were stunned by the beauty of the Arctic landscapes in winter, and some revealed that social media motivated them to continue researching Svalbard, thus reducing their fear of the cold. Regarding the coldness of the "real winter," Norwegian respondent \#22 explained that they wanted to experience a "fairy-tale" winter in order to have the closest possible encounter with the "real" Arctic—as it was part of their country-and to take part in the typical snow activities and to disconnect from life in Oslo.

When focusing on food as another physiological need [6], Longyearbyen was not chosen as a destination to satisfy that need, as it was observed that only $10 \%$ of the respondents mentioned the food as being an important factor for tourism in Svalbard. For example, Norwegian respondent \#45 mentioned that: "The food in the restaurants is fantastic; they have the best menus and skilled chefs from around the world."

For accommodation, which serves another basic need of having shelter [6], most of the hotels in Longyearbyen were ranked as four-star hotels with the exception of one hostel. The common feature among them was that they offered comfortable rooms and spectacular views due to the proximity of the fjords and mountains. Rest and relaxation represented an important need to fulfil [6], and Longyearbyen is considered a non-crowded destination. One of the main goals of many respondents was to be able to connect with the surrounding nature, to be away from towns, pollution, and noise, and to be close to nature. Therefore, recreational activities were key to relaxing both the psyche and the body by dog sledding, for example, which was conducted by $64 \%$ of respondents. The most popular activity was watching the Aurora, as $71 \%$ of respondents had joined this type of excursion. Two other popular activities involved snowmobiling and visiting ice-caves, which was undertaken by $50 \%$ and $25 \%$ of the respondents, respectively. Dutch respondent \#5 shared their need for relaxation and intimacy: "We wanted to have some relaxing days away from the stress of the city, and to enjoy the nature and attractions of this place. Here you have intimacy and you can experience a connection with nature." Social media was revealed as a powerful tool when searching for information about the activities and attractions in Longyearbyen. For example, American respondent \#7 said that after seeing pictures on Instagram, they were fascinated by how well organized the town is, as it has many travel agencies and companies that organize all kinds of activities.

Concerning the "safety needs" (Figure 2, number 2) [6], Longyearbyen is seen as a safe destination. According to the local people, some isolated cases of robberies sometimes occur in regard to Longyearbyen's political and economic position. Svalbard is in Norway, meaning that it has a high standard of living and a peaceful society. However, precautions must be taken on the outskirts of the town due to possible encounters with polar bears.

Regarding “love and belonging” (Figure 2, number 3) [6], Longyearbyen seemed to be a destination that was mostly chosen by couples seeking tranquility, solitude, intimacy, and quality time, and was expressed as a motivation by $36 \%$ of respondents. Families aimed to spend some quality time with their loved ones and have the chance of doing something different with their children. However, a common fear shared among couples that were not traveling with their children was that Longyearbyen is geographically 
far away from the rest of the world, which made them feel worried and anxious about being physically separated from their relatives. For some of the solo travelers, being far away from their family members also represented a challenge and made them feel geographically isolated. Nevertheless, since all outdoor activities in Longyearbyen are held in groups, respondents had the chance to share their feelings and fears with others, despite any age differences. Therefore, this connection facilitated embracing the cold, the extreme weather, and other complications along the excursions to make the experience human and realistic. For example, Brazilian respondent \#13 confessed: "I was afraid of being so far away from my children. In Brazil, nobody knows about this place, and nobody thinks that there are people living so far up North. This place is still unknown for many Brazilians."

Regarding the "esteem" element (Figure 2, number 4) [6], the interviews showed that most respondents were eager to defy their boundaries, regardless of their fears of visiting the High North. Besides, social media was the perfect platform on which to enhance their ego and boast about an experience. For some respondents, the chance of being the first among their peers to reach Longyearbyen represented the opportunity to enhance their esteem. For example, American respondent \#7 confessed that they were proud of showing pictures of their trip on Instagram, and of being the first person among their friends and relatives to go to Longyearbyen: "Not many people know about the Arctic and this world is still unknown for many. That is why my husband and I wanted to be the first ones to discover it and tell our friends about our experience, unless we are eaten by a polar bear!"

"Self-actualization" (Figure 2, number 5) [6] represented the main aim for most of the respondents to travel to Longyearbyen, and was reflected by the urge to have a deep connection with their partners (for couples), by the need to complete a "bucket list," and by reaching the northernmost point of the world and unraveling the mystery of the North Pole. Other needs to be satisfied included going beyond their limits, experiencing new frontiers in terms of remoteness, having the sense of being in the middle of nowhere, challenging themselves, discovering authenticity, feeling a rush of adrenaline, and having the chance to take their family members to such a distant place. All these aspects represented a way of strengthening their potential to the maximum. Indeed, this level of Maslow's hierarchy of needs represented the most interesting one to analyze, since it allowed us to detect the feeling of joy, reward, and gratification as reaching Longyearbyen demands setting aside comfort and being exposed to risks and extreme conditions during the hard winter. For example, American respondent \#11 shared that Svalbard represented the alternative of reaching one of the Poles: "We have traveled around the world a lot. We have been to five continents, and this time we wanted to go to Antarctica, but from doing some research, we discovered that to get there was extremely expensive, so we started thinking of an alternative and discovered Longyearbyen as the northernmost town in the world."

Regarding the travel career ladder element (Figure 2, number 6) [7], Longyearbyen represented a step forward in the travel career experience of respondents. Asking for the number of places that the interviewees had already been to implied whether they were experienced travelers. For some respondents, counting the number of visited countries expressed the way in which they were moving forward in their travel career. In general, Longyearbyen is a destination aimed at eager travelers with an adventurous spirit. This is connected to the inspirational impact of social media (Figure 2, circled number 1). Regarding their travel experience, French respondent \#21 shared that they have already traveled to 42 countries, and that they considered themselves as a world citizen. Moreover, Instagram represented a platform on which to publicly express the number of destinations visited. They confessed being "addicted" to Instagram and that they followed a lot of influencers, adventure travelers, and even destination marketing organizations. They described themselves as a "passionate traveler" that looked for inspiration on social media. Additionally, the term "pattern" [38-40] complemented the concept of the travel career ladder, as many respondents were eager to visit Longyearbyen because it allowed them to follow a passion or specific hobby such as hiking or watching the Aurora.

Travel motivation analysis was identified by the push and pull motivational elements. According to Crompton's seven push motivations [8], the element of "escape from a mundane life" (Figure 2, number 7) was reflected by the respondents' need to get away from their daily routine and escape from 
the stress of the city in order to seek non-crowded destinations. For example, Norwegian respondent \#22, a couple, expressed their need to have three days off from their jobs as teachers in Oslo.

The next push factor, "exploration and evaluation of self" (Figure 2, number 8), implied that according to the respondents, Longyearbyen represented the challenge of facing extreme conditions and unpredictable risks such as avalanches, crevasses, and the possibility of encountering polar bears. Therefore, these Arctic characteristics were the motivations behind challenging themselves to go beyond their limits and fears. For example, Brazilian respondent \#13 wanted to experience the life of ancient Arctic explorers: "We knew about this place [Longyearbyen] thanks to a book from Amyr Klink [a Brazilian writer and explorer]. In his book, he talks about his expedition to Antarctica where he also shares the contrast between the South Pole and the North Pole. It is there that we discovered Svalbard. Our objective was to challenge ourselves and to experience life like Amyr Klink. We were enchanted by his stories about the North Pole and Antarctica, and even though we live closer to Antarctica than Svalbard, it was much cheaper for us to come here."

For the "relaxation" push element (Figure 2, number 9), respondents were interested in joining outdoor activities that could calm their body and mind. As the fourth push motivation "prestige" (number 10) revealed, some respondents gave value to the chance of gaining recognition from others by traveling so far north in the world. Moreover, this shows the need for esteem in Maslow's hierarchy of needs. In addition, the fifth push motivation "regression" (number 11) represented the curiosity factor, as some respondents emphasized the importance of experiencing emotions that are not possible to have in their daily lives, such as riding a snowmobile and feeling an adrenaline rush or the opportunity to feel like a child. In terms of "regression," Mexican respondent \#18 shared that they were excited to use a balaclava (a mask that covers part of the face for extreme weather conditions) and that they laughed with their friends, saying that they felt like the "Michelin man" from so many layers of clothing due to the extreme cold.

For the "enhancement of kinship relations" (Figure 2, number 12), the respondents expressed their need to be emotionally connected as a couple or a family by having the chance to experience quality time as a way of strengthening their relationship, which is related to the "facilitation of social interactions" (number 13). However, the respondents did not mention the need to socialize with new groups of people. All outdoor activities in Svalbard are held in groups, but this fact implied that the destination and its features were more valued than the chance of meeting new people.

The pull motivation [8], "novelty" (Figure 2, number 14), was important regarding the destination of Longyearbyen. Curiosity urged respondents to travel to Svalbard, explore the unknown and a place that is extremely different, and experience the remoteness and the hidden and unspoiled areas of the town's surroundings. Additionally, for the "education" element (Figure 2, number 15), the respondents' primary interest was in the High Arctic's features such the Aurora and the autochthonous species: the polar fox and the polar bear. Hence, $58 \%$ of the participants had a special interest in watching the Aurora, and $30 \%$ were interested in spotting polar bears after being fully aware of the risks involved. Although the dark season was already over at the time of interview, these phenomena awakened the curiosity of many participants.

With respect to social media, $24 \%$ of the respondents stated that either Facebook or Instagram contributed to their decision-making processes of their trip to Longyearbyen. Both platforms were used as sources of information and inspiration (Figure 2, circled number 1) [66], and Instagram hashtags provided respondents with constant updates from posts of other users/travelers. For example, American respondent \#2 said that: "Social media helped me a lot. I looked up some things related to northern Norway, and I saw pictures of Longyearbyen, so I started looking up information, and I wrote to some people that posted pictures on Instagram."

In addition, interviews revealed that most social media followers ranged from teenagers to those in their mid-20s and mid-30s, which illustrates the interest of the younger generation and social media dependence. Moreover, there were some specific cases of respondents who admitted being "addicted" to Instagram, among others who said that social media did not play any role in their travel motivations. 
In addition, social media was also the tool used by the destination marketing organization "Visit Svalbard" in order to encourage travelers to upload their pictures and include their hashtags to market a place after an excursion.

For many respondents, their perception of Longyearbyen changed after being in contact with other users' images and videos posted on Instagram, which consequently reduced their uncertainty or fears of the unknown (Figure 2, circled number 2) [67]. Nevertheless, there were also other respondents that already knew of what to expect from Longyearbyen. These isolated cases were groups of people that had already been to other parts of the Arctic. For example, American respondent \#11 expressed that: "We are always following journalists and hashtags related to different places around the world on Instagram, and after discovering Svalbard, we were amazed by its pictures. I imagined it as an isolated place, and after having seen so many pictures of Longyearbyen, I realized that the trip wouldn't be as risky as I had previously thought." In sum, social media debunked misconceptions of the High Arctic region (Figure 2, circled number 3) [66,67]. For 30\% of the respondents, social media represented access to discover features about Svalbard that were unknown to them. Most of the respondents thought that there was no life at the latitudes in which Longyearbyen is situated, and Svalbard was perceived as an uninhabited and isolated place: a white landscape full of ice caps, no people, and polar bears.

Finally, referring to the travel fear "FOMO" (Figure 2, circled number 4) [70] as a hazard of social media, some respondents were worried about not ever having the chance to visit Svalbard in the future, as the High Arctic is being highly affected by global warming. However, social media not only massively overexposes a destination (Figure 2, circled number 5) but also represents a platform for raising awareness [72,73]. Some respondents' Instagram accounts emphasized the preservation of the unspoiled nature of Svalbard while mentioning how vulnerable the High Arctic is. For example, German respondent \#29 shared this fear: "I actually saw a picture of a polar bear from Svalbard on Instagram and immediately thought that I had to go there. I kind of thought that maybe 1 will never get to see such nature again due to climate change and global warming."

\section{Discussion}

According to the sample analyzed, most of the interview respondents had qualified jobs, and the majority were traveling with their partners or were solo. Following Maslow's theory of needs [6], the weather (i.e., the extreme cold) represented either an attractive feature or concern for some of the respondents. Food, which is perceived as the cuisine of Svalbard, was not a relevant feature to determine whether to travel to Longyearbyen. However, rest or relaxation represented a valuable need to be fulfilled at this destination, since respondents were looking to join activities and have the chance to experience tranquility in the surrounding nature. Further, the "safety needs" were guaranteed, since Svalbard has a stable economic, social, and political position. Concerning "love and belonging," couples desired the experience of intimacy and a connection with their partner. Maslow's "esteem" was represented by the chance of having an experience that would challenge themselves to go beyond their boundaries. For "self-actualization," most respondents aimed to have a unique experience in Svalbard that would allow them to challenge their capacities. Therefore, the analysis of Maslow's motivational theory supports the perspective that Longyearbyen is perceived as a destination for those aiming for the top tier of Maslow's theory.

Regarding the respondents' travel career ladder, Pearce's model [7] helped to identify most of the respondents as experienced travelers. Our findings evidence the idea that Longyearbyen attracts tourists with a vast experience in traveling who are willing to reach the most of their potential, which supports previous studies that stated that the more experience a tourist has in traveling, the greater the likelihood of them reaching the top of Maslow's theory [34-37]. Participants also showed an adventurous spirit as they were willing to actively participate in demanding excursions such as snowmobiling, dog sledding, hiking activities, visiting ice-caves, and hunting the Aurora. These characteristics reinforce the idea that experienced travelers are more determined [32]. 
Crompton's push and pull motivational elements [8] were analyzed and provided the clear understanding that respondents were willing to escape from their daily routine and their natural environments in order to fulfil the need of "escaping from their mundane lives." According to the second push factor, "exploration and evaluation of self," although traveling to Longyearbyen exposes any traveler to risky situations, these features were indeed the ones encouraging the respondents to challenge themselves to push their limits. For the push element "relaxation," survey participants were seeking calmness and tranquility. "Prestige" was represented by having the chance to visit a place that is still unknown by many and, as such, to be able to raise their self-esteem by exploring new frontiers. The push element named "regression" was represented by the need to experience other emotions that respondents could not usually have in their daily routines, such as the chance to participate in a snowmobile excursion and experience a rush of adrenaline.

The sixth push motivation element, "enhancement of kinship relations," was represented by the need to strengthen bonds with respondents' travel companions. The seventh push element, "facilitation of social interactions," was the only one not expected to be satisfied, as respondents were not looking for new friendships when participating in excursions. The attractiveness of natural features was a stronger motivation when compared to social or cultural attractions. However, Longyearbyen's features are already on the side of the pull motivation elements. Here, "novelty" was represented by Svalbard's unique features such as its fauna, natural surroundings, and wilderness. Another pull element, "education," also became relevant as travelers were eager to know more about the Aurora and the local fauna. Therefore, the concept of the push and pull motivations defined by Crompton [6] allowed the understanding that Longyearbyen's features were a strong motive that drove tourists to go further in exploring a destination that would take them out of their routine and allow them to experience unique feelings in connection with the surrounding nature. This finding also reinforces Dann's concept [45] that the internal need to be fulfilled precedes the choice of destination, which means that the push factors were the central point in traveling to Longyearbyen.

Following the survey results on the influence of social media, most users were aged between their mid-20s and mid-30s. Instagram and Facebook proved influential in the decision-making process of the trip to Longyearbyen, as they were used as sources of inspiration and motivation to face the High North. In this sense, respondents had a close encounter with the destination before arriving, which allowed them to bridge the gap between what they imagined about the Arctic and the reality of the tourism in Longyearbyen, which consequently reduced their uncertainty and debunked misconceptions. Svalbard was perceived as an isolated and remote place on Earth where no life could possibly exist. These arguments were expressed by respondents who had never been to the High Arctic before. Therefore, for $30 \%$ of the interviewees, social media represented a means of access to discover features about Svalbard. Moreover, some respondents were astonished to find the attractiveness of the surrounding nature of Longyearbyen and the town's organized community. Thus, the findings regarding social media confirm the idea that while popular platforms such as Facebook and Instagram are not aimed at being travel-related, they allow the opportunity for respondents to discover, become inspired, debunk misconceptions, and go beyond their limits. However, evident hazards of social media use were identified as producing the social anxiety of FOMO and an increased, massive overexposure of Longyearbyen, which supports Przybylski et al. and Lemelin et al. [70,73], who stated that social media fosters social anxiety and produces a counter-productive effect by exposing a destination that is known of being on the verge of ceasing to exist.

\section{Conclusions}

This study adds knowledge to tourism motivational research through its novel approach. The novelty lies in the combination of diverse elements of travel motivation and social media impacts into a single research design, as well as in the proposed model application to the High Arctic which is an underexplored research field. In line with this composite design, two primary research assumptions were qualitatively surveyed in the case of the High Arctic: (1) The relevance of different 
travel motivational elements when choosing Longyearbyen as a destination, and (2) the impact of the different aspects of social media on travel motivation elements to visit Longyearbyen.

The fusion of motivation and social media elements resulted in 20 elements, which were addressed from the respondents and discussed in this research. In this regard, the Longyearbyen survey provided enough novel empirical information to understand how travel motivation and social media impact the context of the High Arctic destination. Therefore, studying the travel motivation behind visiting a destination allowed this research to acknowledge what is expected from this destination to accommodate travelers' needs. This material can help inform destination managers and future research on travelers' motivations and needs.

From the perspective of future tourism development in the archipelago, the respondents stressed the high importance of its environmental attractiveness, specialty, and unspoiled originality. Thus, it is imperative for destination managers to foster the protection and preservation of one of the most vulnerable places on Earth, since tourism is responsible for the effects of climate change and environmental damage due to its high growth [77]. Svalbard is entering into the public eye from being on the verge of ceasing to exist, and this fact produces anxiety in travelers hoping to be lucky enough to visit Svalbard to still appreciate its wilderness and fauna. This matter urges a call to both demand and stimulate "responsible tourism behavior based on the concept of sustainable tourism" [78] which might be addressed through travel motivation needs and social media. As Breiby, Duedahl, Øian, and Ericsson [79] suggested, sustainable measures should engage tourists as active collaborators by offering them purposeful, emotional, and unforgettable experiences in connection with the natural and cultural environment. In this way, this action could foster an interest in achieving the more sustainable development of the destination [80], since a collaboration of the stakeholders is key in environmental care and protection [81] and can be easily supported by social media. Therefore, this study suggests using the proposed model on travel motivations and social media to monitor and actively manage travel behavior to build responsibility for sustainable development in an endangered destination like Svalbard. Further, this study informs tourism destination managers to make every possible effort to enhance travel motivation through the use of social media as a positive force by focusing on the opportunities they offer.

Further research should test the proposed model using a quantitative research approach to enable studying the relationship among the elements and provide conclusive advice on how to directly address travel motivation and responsibility through social media elements.

This study is not without limitations. It included interviews conducted between the months of February and March 2019. Therefore, this study could be extrapolated to the whole winter period in order to identify whether respondents' profiles and patterns coincide, which could establish a pattern among travelers that choose the winter months to travel to Longyearbyen. In addition, it would be interesting to see if travel motivations change for those who decide to travel there during the summer.

Author Contributions: Conceptualization, C.A. and T.A.M.; methodology, C.A. and T.A.M.; investigation, C.A.; writing—original draft preparation, C.A.; writing—review and editing, T.A.M.; visualization, T.A.M.; supervision, T.A.M.; project administration, C.A.; funding acquisition, C.A. and T.A.M. All authors have read and agreed to the published version of the manuscript.

Funding: This research was funded by the Slovenian Research Agency under Grant P5-0117.

Conflicts of Interest: The authors declare that there is no conflict of interest.

\section{References}

1. Address of Senator John F. Kennedy Accepting the Democratic Party Nomination for the Presidency of the United States-Memorial Coliseum, Los Angeles, 15 July 1960. Available online: https://www.presidency.ucsb. edu/documents/address-senator-john-f-kennedy-accepting-the-democratic-party-nomination-for-the (accessed on 25 March 2020).

2. Manley, B.; Elliot, S.; Jacobs, S. Expedition Cruising in the Canadian Arctic: Visitor Motives and the Influence of Education Programming on Knowledge, Attitudes, and Behaviours. Resources 2017, 6, 23. [CrossRef] 
3. Dunkley, R.; Morgan, N.; Westwood, S. Visiting the trenches: Exploring meanings and motivations in battlefield tourism. Tour. Manag. 2011, 32, 860-868. [CrossRef]

4. Isaac, R.K.; Nawijn, J.; Van Liempt, A.; Gridnevskiy, K. Understanding Dutch visitors' motivations to concentration camp memorial sites. Curr. Issues Tour. 2019, 22, 747-762. [CrossRef]

5. Knollenberg, W.; McGehee, N.G.; Bynum, B.; Clemmons, D. Motivation-based transformative learning and potential volunteer tourists: Facilitating more sustainable outcomes. J. Sustain. Tour. 2014, 22, 922-941. [CrossRef]

6. Maslow, A.H. A Theory of Human Motivation. Psychol. Rev. 1943, 50, 370-396. [CrossRef]

7. Pearce, P.L. The Ulysses Factor: Evaluating Visitors in Tourist Settings; Springer: New York, NY, USA, 1988. [CrossRef]

8. Crompton, J.L. Motivations for pleasure vacation. Ann. Tour. Res. 1979, 6, 408-424. [CrossRef]

9. Statistics Norway. This Is Svalbard 2016. Available online: https://www.ssb.no/en/befolkning/artikler-ogpublikasjoner/this-is-svalbard-2016 (accessed on 26 March 2019).

10. Kaltenborn, B.P.; Emmelin, L. Tourism in the high north: Management challenges and recreation opportunity spectrum planning in Svalbard, Norway. Environ. Manag. 1993, 17, 41-50. [CrossRef]

11. Visit Svalbard. Information. Available online: https://en.visitsvalbard.com/visitor-information/corporatesite/masterplan (accessed on 20 March 2020).

12. Visit Svalbard. Statistics from Visit Svalbard. Available online: https://en.visitsvalbard.com/dbimgs/ StatistikkfraVisitSvalbardASper2018forweb.pdf (accessed on 29 April 2019).

13. Lee, Y.; Weaver, D.B.; Prebensen, N.K. Arctic Tourism Experiences: Production, Consumption and Sustainability; CABI Publishing: Wallingford, UK, 2017.

14. Grydehøj, A. Informal diplomacy in Norway's Svalbard policy: The intersection of local community development and Arctic international relations. Glob. Chang. Peace Secur. 2014, 26, 41-54. [CrossRef]

15. The University Centre in Svalbard [UNIS]. Study in Svalbard. Available online: https://www.unis.no/studies (accessed on 26 March 2019).

16. Association of Arctic Expedition Cruise Operators [AECO]. Cruise Study Svalbard. Available online: https://www.aeco.no/wp-content/uploads/2019/09/2019-Epinion-Cruise-Study-AECO-and-VisitSvalbardFinal-report.pdf (accessed on 30 March 2020).

17. Hall, C.M.; Saarinen, J. Polar tourism: Definitions and dimensions. Scand. J. Hosp. Tour. 2010, 10, 448-467. [CrossRef]

18. Denstadli, J.M.; Jacobsen, J.K.S. More clouds on the horizon? Polar tourists' weather tolerances in the context of climate change. Scand. J. Hosp. Tour. 2014, 14, 80-99. [CrossRef]

19. Visit Svalbard. Where to Stay. Available online: https://en.visitsvalbard.com/where-to-stay/searchresults? sr=1\&poly $=504083$ (accessed on 11 April 2019).

20. Baldacchino, G. Extreme Tourism: Lessons from the World's Coldwater Islands; Routledge: Abingdon, UK, 2006.

21. Lindberg, F.; Eide, D. Challenges of extraordinary experiences in the Arctic. J. Consum. Behav. 2016, 15, 15-27. [CrossRef]

22. Mihalic, T.; Šegota, T.; Knezević Cvelbar, L.; Kuščer, K. The influence of the political environment and destination governance on sustainable tourism development: A study of bled, Slovenia. J. Sustain. Tour. 2016, 24, 1489-1505. [CrossRef]

23. Saarinen, J.; Tervo, K. Perceptions and adaptation strategies of the tourism industry to climate change: The case of Finnish nature-based tourism entrepreneurs. Int. J. Innov. Sustain. Dev. 2006, 1, 214-228. [CrossRef]

24. Scott, D. Global environmental change and mountain tourism. In Tourism and Global Environmental Change; Gossling, S., Hall, C.M., Eds.; Routledge: Abingdon, UK, 2006; pp. 54-75.

25. Tervo-Kankare, K. The consideration of climate change at the tourism destination level in Finland: Coordinated collaboration or talk about weather? Tour. Plan. Dev. 2011, 8, 399-414. [CrossRef]

26. McDonald, M.G.; Wearing, S.; Ponting, J. The nature of peak experience in wilderness. J. Humanist. Psychol. 2009, 37, 370-385. [CrossRef]

27. Saarinen, J. Nordic Perspectives on Tourism and Climate Change Issues. Scand. J. Hosp. Tour. 2014, 14, 1-5. [CrossRef] 
28. Scott, D.; Hall, C.M.; Stefan, G. Tourism and Climate Change: Impacts, Adaptation and Mitigation; Routledge: Abingdon, UK, 2012. [CrossRef]

29. Lin, Y.K.; Nawijn, J. The impact of travel motivation on emotions: A longitudinal study. J. Destin. Mark. Manag. 2020, 16, 100363. [CrossRef]

30. Farmaki, A. An exploration of tourist motivation in rural settings: The case of Troodos, Cyprus. Tour. Manag. Perspect. 2012, 2, 72-78. [CrossRef]

31. Hsu, C.H.; Huang, S. Travel motivation: A critical review of the concept's development. Tour. Manag. Anal. Behav. Strat. 2008, 14-27. [CrossRef]

32. Pearce, P.L.; Caltabiano, M.L. Inferring travel motivation from travellers' experiences. J. Travel Res. 1983, 22, 16-20. [CrossRef]

33. Ryan, C. The travel career ladder: An appraisal. Ann. Tour. Res. 1998, 25, 936-957. [CrossRef]

34. Huang, S.; Hsu, C.H. Travel motivation: Linking theory to practice. Int. J. Cult. Hosp. Res. 2009, 3, $287-295$. [CrossRef]

35. Poldma, T. Hierarchy of Needs (Maslow). In The Bloomsbury Encyclopedia of Design; Bloomsbury Academic: London, UK, 2016; p. 150. [CrossRef]

36. Taormina, R.J.; Gao, J.H. Maslow and the motivation hierarchy: Measuring satisfaction of the needs. Am. J. Psychol. 2013, 126, 155-177. [CrossRef] [PubMed]

37. Ivtzan, I.; Gardner, H.E.; Bernard, I.; Sekhon, M.; Hart, R. Wellbeing through self-fulfilment: Examining developmental aspects of self-actualization. Humanist. Psychol. 2013, 41, 119-132. [CrossRef]

38. Perrett, C.A. Travel Motivation of Independent Youth Leisure Travellers. Master's Thesis, University of Manitoba, Winnipeg, MB, Canada, 2007.

39. Blichfeldt, B.S. A nice vacation: Variations in experience aspirations and travel careers. J. Vacat. Mark. 2007, 13, 149-164. [CrossRef]

40. Pearce, P.L.; Lee, U.I. Developing the travel career approach to tourist motivation. J. Travel Res. 2005, 43, 226-237. [CrossRef]

41. Gnoth, J. Tourism motivation and expectation formation. Ann. Tour. Res. 1997, 24, 283-304. [CrossRef]

42. Wu, M.Y.; Pearce, P.L. Chinese recreational vehicle users in Australia: A netnographic study of tourist motivation. Tour. Manag. 2014, 43, 22-35. [CrossRef]

43. Devesa, M.; Laguna, M.; Palacios, A. The role of motivation in visitor satisfaction: Empirical evidence in rural tourism. Tour. Manag. 2010, 31, 547-552. [CrossRef]

44. Parrinello, G.L. Motivation and anticipation in post-industrial tourism. Ann. Tour. Res. 1993, 20, $233-249$. [CrossRef]

45. Dann, G.M. Tourist motivation: An appraisal. Ann. Tour. Res. 1981, 8, 187-219. [CrossRef]

46. Prayag, G.; Ryan, C. The relationship between the 'push' and 'pull' factors of a tourist destination: The role of nationality-An analytical qualitative research approach. Curr. Issues Tour. 2011, 14, 121-143. [CrossRef]

47. Mill, R.; Morrison, A. The Tourism System; Prentice-Hall: Englewood Cliffs, NJ, USA, 1985.

48. Huertas, A.; Marine-Roig, E. User reactions to destination brand contents in social media. Inf. Technol. Tour. 2016, 15, 291-315. [CrossRef]

49. Goossens, C. Tourism information and pleasure motivation. Ann. Tour. Res. 2000, 27, 301-321. [CrossRef]

50. Kozak, M. Comparative analysis of tourist motivations by nationality and destinations. Tour. Manag. 2002, 23, 221-232. [CrossRef]

51. Lau, A.; McKercher, B. Exploration versus acquisition: A comparison of first-time and repeat visitors. J. Travel Res. 2004, 42, 279-285. [CrossRef]

52. Yoon, Y.; Uysal, M. An examination of the effects of motivation and satisfaction on destination loyalty: A structural model. Tour. Manag. 2005, 26, 45-56. [CrossRef]

53. Hsu, C.H.; Cai, L.A.; Li, M. Expectation, motivation, and attitude: A tourist behavioral model. J. Travel Res. 2010, 49, 282-296. [CrossRef]

54. Whyte, L.J. Understanding the relationship between push and pull motivational factors in cruise tourism: A canonical correlation analysis. Int. J. Tour. Res. 2017, 19, 557-568. [CrossRef]

55. Caber, M.; Albayrak, T. Push or pull? Identifying rock climbing tourists' motivations. Tour. Manag. 2016, 55, 74-84. [CrossRef] 
56. Oliveira, T.; Araujo, B.; Tam, C. Why do people share their travel experiences on social media? Tour. Manag. 2020, 78, 104041. [CrossRef]

57. Pino, G.; Peluso, A.M.; Del Vecchio, P.; Ndou, V.; Passiante, G.; Guido, G. A methodological framework to assess social media strategies of event and destination management organizations. J. Hosp. Mark. Manag. 2019, 28, 189-216. [CrossRef]

58. Wang, S.; Kirillova, K.; Lehto, X. Travellers' food experience sharing on social network sites. J. Travel Tour. Mark. 2017, 34, 680-693. [CrossRef]

59. Tran, V.T.; Hue, H.D.; Nguyen, T.N.; Phan, N.V.N. An impact of social media on online travel information search in Vietnam. J. Hosp. Tour. Res. 2017, 3, 509-512. [CrossRef]

60. Sotiriadis, M.D. Sharing tourism experiences in social media: A literature review and a set of suggested business strategies. Int. J. Contem. Hosp. Manag. 2017, 29, 179-225. [CrossRef]

61. Filieri, R.; Alguezaui, S.; McLeay, F. Why do travelers trust TripAdvisor? Antecedents of trust towards consumer-generated media and its influence on recommendation adoption and word of mouth. Tour. Manag. 2015, 51, 174-185. [CrossRef]

62. Hays, S.; Page, S.J.; Buhalis, D. Social media as a destination marketing tool: Its use by national tourism organisations. Curr. Issues Tour. 2013, 16, 211-239. [CrossRef]

63. Jabreel, M.; Moreno, A.; Huertas, A. Semantic comparison of the emotional values communicated by destinations and tourists on social media. J. Dest. Mark. Manag. 2016, 6, 170-183. [CrossRef]

64. Narangajavana, Y.; Callarisa Fiol, L.J.; Moliner Tena, M.Á.; Rodríguez Artola, R.M.; Sánchez García, J. The influence of social media in creating expectations. An empirical study for a tourist destination. Ann. Tour. Res. 2017, 65, 60-70. [CrossRef]

65. Munar, A.M.; Jacobsen, J.K.S. Trust and involvement in tourism social media and web-based travel information sources. Scand. J. Hosp. Tour. 2013, 13, 1-19. [CrossRef]

66. Mariani, M.; Ek Styven, M.; Ayeh, J.K. Using Facebook for travel decision- making: An international study of antecedents. Int. J. Contem. Hosp. Manag. 2019, 31, 1021-1044. [CrossRef]

67. Fatanti, M.N.; Suyadnya, I.W. Beyond user gaze: How Instagram creates tourism destination brand? Procedia Soc. Behav. Sci. 2015, 211, 1089-1095. [CrossRef]

68. Llodra-Riera, I.; Martínez-Ruiz, M.P.; Jiménez-Zarco, A.I.; Izquierdo-Yusta, A. Assessing the influence of social media on tourists' motivations and image formation of a destination. Int. J. Qual. Serv. Sci. 2015, 7, 458-482. [CrossRef]

69. Vannucci, A.; Flannery, K.M.; Ohannessian, C.M. Social media use and anxiety in emerging adults. J. Affect. Disord. 2017, 207, 163-166. [CrossRef]

70. Przybylski, A.K.; Murayama, K.; DeHaan, C.R.; Gladwell, V. Motivational, emotional, and behavioural correlates of fear of missing out. Comput. Hum. Behav. 2013, 29, 1841-1848. [CrossRef]

71. Hetz, P.R.; Dawson, C.L.; Cullen, T.A. Social media use and the fear of missing out (FoMO) while studying abroad. J. Res. Tech. Educ. 2015, 47, 259-272. [CrossRef]

72. Joo, Y.; Seok, H.; Nam, Y. The Moderating Effect of Social Media Use on Sustainable Rural Tourism: A Theory of Planned Behavior Model. Sustainability 2020, 12, 4095. [CrossRef]

73. Lemelin, H.; Dawson, J.; Stewart, E.J.; Maher, P.; Lueck, M. Last-chance tourism: The boom, doom, and gloom of visiting vanishing destinations. Curr. Issues Tour. 2010, 13, 477-493. [CrossRef]

74. Viken, A. What is Arctic tourism, and who should define it? In New Issues in Polar Tourism; Springer: Dordrecht, The Netherlands, 2013; pp. 37-50.

75. Jennings, G. Tourism Research, 2nd ed.; John Wiley \& Sons Ltd.: Milton, Qld, Australia, 2010.

76. Farrell, S. 28 Tips for Creating Great Qualitative Surveys. Available online: https://www.nngroup.com/ articles/qualitative-surveys (accessed on 19 July 2019).

77. Koens, K.; Postma, A.; Papp, B. Is overtourism overused? Understanding the impact of tourism in a city context. Sustainability 2018, 10, 4384. [CrossRef]

78. Mihalic, T. Sustainable-responsible tourism discourse-Towards 'responsustable' tourism. J. Clean. Prod. 2016, 111, 461-470. [CrossRef]

79. Breiby, M.A.; Duedahl, E.; Øian, H.; Ericsson, B. Exploring sustainable experiences in tourism. Scand. J. Hosp. Tour. 2020, 1-17. [CrossRef] 
80. Kuščer, K.; Mihalič, T. Residents' attitudes towards overtourism from the perspective of tourism impacts and cooperation-The case of Ljubljana. Sustainability 2019, 11, 1823. [CrossRef]

81. Gogonea, R.M.; Baltălungă, A.A.; Nedelcu, A.; Dumitrescu, D. Sustainable tourism aims to channel tourism to the advantage of all stakeholders-Destination places and communities, tourists and all the associated activities and services. Tourism pressure at the regional level in the context of sustainable development in Romania. Sustainability 2017, 9, 698. [CrossRef] 